\title{
Satisfaction of Patients Family Reviewed from Caring Human Resources Psychiatic Poly in Hospital Muhammadiyah University of Malang
}

\author{
Hari Rachmawati ${ }^{1}$, Sandu \\ Siyoto $^{2}$, Nurdina ${ }^{2}$ \\ ${ }^{1}$ Magister of Health Study \\ Program of Institut Ilmu Kesehatan \\ STRADA Indonesia \\ ${ }^{2}$ Lecturer of Institut Ilmu \\ Kesehatan STRADA Indonesia \\ Email: \\ hrahmawati81@gmail.com
}

Received : October 12, 2019

Accepted : February 13, 2020

Published : May 10, 2020

\begin{abstract}
Patient family satisfaction is the most important thing so that the hospital can develop. This can be created if medical personnel are able to provide good service. One indicator to support optimal service is to manage caring of appropriate human resources. Therefore, the purpose of this study was to determine the effect between caring human resources and family satisfaction of patients in Muhammadiyah University Hospital Malang. The study design used cross sectional. The sample of this study amounted to 110 .

This study used a random sampling stratification technique with research instruments using a questionnaire. In addition, the data analysis technique uses simple linear regression. Based on the data collection results obtained 108 respondents $(98.2 \%)$ gave a good assessment of caring human resources, 2 respondents $(1.8 \%)$ gave sufficient ratings, 79 respondents $(71.8 \%)$ felt very satisfied, and 31 respondents $(28.2 \%)$ were satisfied with the service at the hospital. Besides that simple linear test results show Sig. amounting to 0,000 (Sig. <0.05), which means that there is an influence of patient family satisfaction in poly psychiatry in terms of caring human resources as much as caring human resources affect the patient's family satisfaction by $15.7 \%(\beta=0.157)$, and $84 \%$ others can be influenced or explained by other variables not included in this study. Based on these results it can be concluded that the management of good and appropriate caring of human resources will produce quality services that have a positive impact on the hospital by increasing patient family satisfaction and increasing number of visits because the hospital is considered appropriate and considered good in providing services.
\end{abstract}

Keywords: Hospitasl, satisfaction, human resources caring

\section{cc) (†) ()}

This is an open-acces article distributed under the terms of the Creative Commons Attribution-ShareAlike 4.0 International License. 


\section{INTRODUCTION}

One of the goals of health development in Indonesia is an effort to improve the quality of health services. This quality service must be able to be implemented in all government and private health care facilities, so that it is expected that the community will be more interested in utilizing health service facilities starting from the level of puskesmas, hospitals and other health care facilities. Hospitals are capital-intensive, technology-intensive and labor intensive public health service institutions which involve human resources with various skills. The reach and quality of health services is very dependent on the capacity and quality of personnel in health care institutions (Djojosugito, 2009).

Hospitals have undergone a paradigm shift that initially only focused on curative and rehabilitative care efforts, but the subsequent development of the hospital is required to play an active role in promotive and preventative efforts. One of the factors that must be considered in developing a hospital is the human resources that the hospital has. Human resources owned greatly influence the success or failure of the services provided by the hospital (Aditama, 2009).

Patient satisfaction is the main thing that needs to be prioritized by the hospital in order to survive, compete and maintain the existing market because the hospital is a business entity engaged in health services. To achieve service quality in accordance with market standards, the hospital always prioritizes customer satisfaction through continuous improvement in service quality with the implementation of correct practices, increasing the competence of human resources (HR) and the application of adequate technology. One characteristic that stands out is the competitive nature that is the basis for developing the quality of hospital services and to achieve service quality in accordance with standards, it requires an organization that is flexible (not rigid), which can adjust to the development of the environment from hospital services (Tjiptono \& Chandra 2011).

Organizing a system, such as a hospital, will not be separated from human resources (HR) in the organization of the hospital. Human resource management is essentially an integral part of overall hospital management (Soeroso, 2008). The success of a hospital is largely determined by the knowledge, skills, creativity and motivation of its staff and employees. The need for skilled workers in various fields in a hospital is already a demand of the global world that cannot be postponed. The presence of technology and other resources is only a tool or supporting material, because ultimately HR is the most decisive (Danim, 2009).

Various facts indicate a serious problem in the quality of health services in Indonesia. This is due to the absence of the best quality control system that can be applied. A deeper understanding of good governance is one of the efforts towards the realization of better quality health services (Azwar, 2009).

Health services that have not been completed with patient expectations are expected to be input for health service organizations to strive to fulfill them. If the performance of health services obtained by patients at a health service facility is in line with their expectations, patients will always come to the health care facility. Patients will always seek health services at facilities whose health service performance can meet patient expectations (Pohan, 2007).

The quality of health services needs to be improved because the needs of the community or individuals for health are in accordance with the standards by using resources fairly, efficiently, effectively within the limited capacity of the government and the community, as well as being held safely and satisfactorily according to good norms and ethics. Health services, both at the Polindes, Pustu, Puskesmas, hospitals, or other health care institutions, are a system that consists of various interrelated, interdependent, and mutually influencing components. The quality of health services in health centers and hospitals is the final product of the interaction and dependency of service aspects (Ningrum, 2014).

Satisfaction is someone's pleasure that comes from a comparison between the pleasure of activities and a product service with the expectation of satisfaction. This patient satisfaction can be created through good service by medical staff in health agencies. Thus if the service is not good, patients who feel dissatisfied will file complaints at the hospital. Complaints that are not immediately addressed will result in decreased patient satisfaction with the capability of health services at the hospital. Consumer satisfaction has become a central concept in business and management discourse. 


\section{METHODS}

The study design used cross sectional. The sample of this study amounted to 110 . This study used a random sampling stratification technique with research instruments using a questionnaire. In addition, the data analysis technique uses simple linear regression.

\section{RESULTS}

Subject Characteristics

Table 1. The characteristics of the respondents in this study included the age of sex, education, employment, patient family satisfaction and caring of human resources

\begin{tabular}{|c|c|c|c|}
\hline No & Characteristics & $\Sigma \mathbf{N}$ & $\Sigma \%$ \\
\hline \multirow[t]{5}{*}{1} & Age (year) & & \\
\hline & $<20$ & 8 & 7,3 \\
\hline & $20-40$ & 61 & 55,45 \\
\hline & $41-60$ & 35 & 31,81 \\
\hline & $>60$ & 6 & 5,45 \\
\hline \multirow[t]{3}{*}{2} & Gender & & \\
\hline & Man & 51 & 46,4 \\
\hline & Female & 59 & 53,6 \\
\hline \multirow[t]{7}{*}{3} & Education & & \\
\hline & Elementary school & 7 & 6,4 \\
\hline & Junior high school & 26 & 23,63 \\
\hline & High school & 47 & 42,7 \\
\hline & Diploma & 1 & 0,90 \\
\hline & Bachelor & 25 & 22,72 \\
\hline & Magister & 4 & 3,63 \\
\hline \multirow[t]{13}{*}{4} & Occupation & & \\
\hline & Student & 3 & 3,72 \\
\hline & Private & 37 & 33,6 \\
\hline & Traders & 8 & 7,3 \\
\hline & Laborer & 11 & 10 \\
\hline & IRT & 7 & 6,36 \\
\hline & Civil servants & 4 & 3,63 \\
\hline & Does not work & 6 & 5,45 \\
\hline & Farmer & 4 & 3,63 \\
\hline & Drug officer & 8 & 7,3 \\
\hline & Nurse & 10 & 9,09 \\
\hline & Registration officer & 8 & 7,3 \\
\hline & Doctor & 4 & 3,63 \\
\hline \multirow[t]{3}{*}{5} & Patient family satisfaction & & \\
\hline & Very satisfied & 79 & 71,8 \\
\hline & Satisfied & 31 & 28,2 \\
\hline \multirow[t]{4}{*}{6} & Caring of human resources & & \\
\hline & Good & 108 & 98,2 \\
\hline & Enough & 2 & 1,8 \\
\hline & Total & 110 & 100 \\
\hline
\end{tabular}


STATISTICAL TEST RESULTS

Tabel 2. Simple Linear Test

Model Summary

\begin{tabular}{|l|r|r|r|r|}
\hline Model & \multicolumn{1}{|c|}{ R } & R Square & Adjusted R Square & Std. Error of the Estimate \\
\hline 1 &, $396^{\mathrm{a}}$ &, 157 &, 149 & 4,289 \\
\hline
\end{tabular}

a. Predictors: (Constant), skortotalX

Tabel 3.

Coefficients $^{\mathbf{a}}$

\begin{tabular}{|rr|r|r|r|r|r|}
\hline \multirow{2}{*}{ Model } & \multicolumn{2}{|c|}{ Unstandardized Coefficients } & $\begin{array}{l}\text { Standardized } \\
\text { Coefficients }\end{array}$ & \multirow{2}{*}{ Sig. } & \\
\cline { 3 - 5 } & \multicolumn{1}{|c|}{ B } & Std. Error & \multicolumn{1}{c|}{ Beta } & & \\
\hline \multirow{2}{*}{1} & (Constant) & 29,133 & 3,331 & & 8,746 &, 000 \\
& skortotalX &, 327 &, 073 &, 396 & 4,484 &, 000 \\
\hline
\end{tabular}

a. Dependent Variable: skortotalY

From the statistical tests to determine the family satisfaction of patients in the psychiatric clinic in terms of caring human resources at the Muhammadiyah University Hospital in Malang, the results of the Sig. amounting to 0,000 (Sig. <0.05), which means that there is a family satisfaction of patients in the psychiatric poly in terms of caring human resources at the Muhammadiyah University Hospital in Malang. The table above also explains if $Y=29.133+0.327 X$. This shows that every addition to one caring variable human score will increase the family satisfaction of patients in the psychiatric poly at 0.327. So, the higher the caring of human resources, the higher the family satisfaction of patients in poly psychiatry. Other results show that caring human resources has an effect on patient family satisfaction by $15.7 \%(\beta=0.157)$, and $84 \%$ can be influenced or explained by other variables not included in this study.

\section{DISCUSSION}

\section{Patient Family Satisfaction}

From table 1 shows that the patient's family satisfaction in the University of Muhammadiyah Malang Hospital most respondents were very satisfied as many as 71 respondents $(71.8 \%)$, and respondents were satisfied as many as 39 respondents $(28.2 \%)$.

From these data indicate that most patients feel very satisfied after getting health services at the University of Muhammadiyah Malang Hospital which is influenced by several factors including age, gender, education and employment.

Based on the age of the respondents, most of the respondents were 20-40 years old, namely 49 respondents (44.54\%) who stated that they were very satisfied after getting services at the hospital. Based on gender, most of the respondents were female, as many as 42 respondents (38.2\%) who stated that they were very satisfied after getting services at the hospital. Based on education, most of the respondents had high school education, namely as many as 34 respondents (30.90\%) who said they were very satisfied after getting services at the hospital. Based on the work, most of the respondents had jobs as private employees, namely 27 respondents $(24.54 \%)$ who stated that they were very satisfied after getting services at the hospital.

Hermanto (2010) said the patient's family satisfaction was judged by the patient's family interpretation of the service received according to what they expected, such as skills, and politeness of officers, the completeness of facilities and infrastructure in providing a health service.

According to Berry and Parasuraman (2005) there are five dominant factors or determinants of service quality, which ultimately become determinants of satisfaction levels. The five determinants of quality are Reability, Responsiveness, Assurance, Emphaty (empathy) and Tangibel (tangible). Reability (reliability) the ability of employees of Muhammadiyah University Malang Hospital to provide services in accordance with the promised, trusted, accurate and consistent in accordance with 
the mission of the hospital. Responsiveness the willingness of employees and owners of institutions to help customers and provide services quickly and meaningfully and the willingness to hear and resolve complaints submitted by patients. The ability of employees of the poor Muhammadiyah university hospital creates confidence and trust in the promises put forward by consumers, so there is assurance. The willingness of employees of Malang Muhammadiyah University Hospital and managers to care more about giving personal attention to customers, thus creating Emphaty (empathy). The appearance of the physical facilities of the Muhammadiyah University Hospital, equipment and various communication materials exist and are sufficient to provide Tangibel (tangible) health services.

The efforts of health workers in providing services in accordance with the wishes and understanding of patient needs, providing information to patients before providing services, helping if there are patient problems, responding to patient complaints, receiving and serving patients well, will determine the patient's perception of the services that have been given to be positive or the patient feels very satisfied. But in providing services, health workers are still lacking in carrying out actions appropriately and precisely, are not dexterous in providing services, and are less open in providing information about the illness so that patients are dissatisfied with the services provided. Thus improving and improving the quality of services is very helpful for hospitals in providing satisfaction services to the families of patients as customers or service recipients.

In health services satisfaction is very important for patients, because patients who are satisfied with the services provided by officers can increase the number of visits, because patients will be loyal to the hospital (as a service provider) so that later the patient will again use these health services. The increase in the number of visits will have a positive impact on the hospital because the hospital is considered feasible and is considered good in providing services.

\section{Caring for Human Resources}

From table 1 shows that Caring for Human Resources at Muhammadiyah University Hospital in Malang is known from 110 respondents giving a good rating of 108 respondents (98.2\%), and giving enough votes as much as 2 respondents (1.8\%).

Indicators of caring human resources include attitudes and mindsets, intensive programs, training programs, developing and motivating abilities. With good judgment, enough, lack of human resource management in Muhammadiyah University Hospital in Malang by respondents is influenced by various factors including age, gender, education and employment.

Based on the age group of respondents, the majority of respondents were aged 20-40 years and stated caring human resources 61 respondents $(55.45 \%)$. Based on the sex of the majority of respondents were female and stated caring good human resources as many as 59 respondents (53.6\%). Based on education, most of the respondents had high school education and stated that caring for good human resources was 47 respondents $(42.7 \%)$. Based on work, most of the respondents had jobs as private employees and stated that they were caring for good human resources as many as 37 respondents $(33.6 \%)$.

Caring for human resources is one of the fields of general caring which includes aspects of planning, organizing, implementing and controlling (Siagian, 2010). The success of an organization depends on the ability of caring in harmonizing the elements of employees with the system, organizational structure, technology, tasks, organizational culture and environment (Sopiah, 2008). The success of a health service is largely determined by the knowledge, skills, nature of staff and employees. Therefore, the role of human resources greatly determines the success of its services (Masruroh, 2015).

The relationship between service personnel and patients is the main factor determining whether or not the services provided by health workers, because patients will feel satisfied after getting service if the services provided by health workers feel satisfied to get the convenience of service. Existing human resources have provided freedom of service to patients to make the desired service choices. Knowledge and technical competencies of qualified human resources have provided services by applying ethical values such as discipline and teamwork, providing services in accordance with existing procedures, and showing a positive attitude with direct contact with patients to find out patient complaints about the services provided. The effectiveness of services provided is always guided by the hospital's vision and mission. Applying 5S work culture (smile, greetings, greetings, courtesy and courtesy) can provide additional value for human resources or health workers in providing quality 
services. The security of the action given to patients is always prioritized, therefore human resources at the hospital are always assessed once a year in September.

Thus attitudes and mindsets, intensive programs, training programs and developing skills to motivate employees are the main factors for human resources or service providers (hospitals). With good service quality, patients will be satisfied with the services provided in accordance with the procedures and needs of patients.

\section{Analysis of the Influence of Patient Family Satisfaction Viewed from Caring Human Resources}

Based on table 1 it is known that the majority of respondents gave a good assessment of caring human resources and felt very satisfied as many as 78 respondents $(70.90 \%)$. From these data indicate that most patients feel very satisfied after getting health services at the University of Muhammadiyah Malang Hospital, and 30 respondents $(27.27 \%)$ stated that the assessment was good for caring human resources with patients who were satisfied that were influenced by other factors.

From the results of a simple linear test table 4.12 statistical tests to determine the family satisfaction of patients in psychiatric poly in terms of caring human resources in the hospital Muhammadiyah University Malang, the results of the Sig. amounting to 0,000 (Sig. <0.05), which means that there is a family satisfaction of patients in the psychiatric poly in terms of caring human resources at the Muhammadiyah University Hospital in Malang. The table above also explains if $\mathrm{Y}=$ $29.133+0.327 \mathrm{X}$. This shows that every addition to one caring variable human score will increase the family satisfaction of patients in the psychiatric poly at 0.327 . So, the higher the caring of human resources, the higher the family satisfaction of patients in poly psychiatry. Other results show that caring human resources has an effect on patient family satisfaction by $15.7 \%(\beta=0.157)$, and $84 \%$ can be influenced or explained by other variables not included in this study.

Caring human resources is a collection of knowledge about how mamanage (managing) human resources should cover aspects of planning, organizing, implementing and controlling (Siagian, 2008). Patient family satisfaction is assessed based on patient interpretation of the service received is in accordance with what they expect such as skills, and courtesy officers, completeness of facilities and infrastructure in providing a health service (Hermanto, 2010).

From the results of the study, it is known that caring for human resources in hospitals shows good criteria so that it can increase the patient's family satisfaction. However, to further improve the quality of health services, caring for human resources must further implement and socialize the hospital's vision and mission. With the existence of the vision and mission so that it can motivate the improvement of quality health services. The application of the $5 \mathrm{~S}$ culture (Smile, Greetings, Greetings, Courteous and Courteous) can also help in providing services that can provide satisfaction to the patient's family.

If caring for human resources is managed properly in accordance with established procedures or rules, it will produce quality health services. So that it will increase the patient's family satisfaction. If the patient's family satisfaction increases it will create patient loyalty to the hospital, especially those who provide quality services that are appropriate to the patient's needs, resulting in satisfaction. Thus the management of caring good human resources and aims to improve the quality of health services, becomes a determinant of the level of satisfaction of the patient's family.

\section{CONCLUSION}

Patient family satisfaction in Muhammadiyah University Hospital Malang has a very satisfied category as many as 79 respondents (71.8\%), satisfied categories as many as 31 respondents $(28.2 \%)$ of the total respondents as many as 110 respondents.

Caring for human resources in Muhammadiyah University Hospital Malang has a good category of 108 respondents $(98.2 \%)$, adequate categories, namely as many as 2 respondents $(1.8 \%)$ of the total respondents as many as 110 respondents.

There is an influence of family satisfaction of patients viewed from caring human resources in Muhammadiyah University Hospital Malang. 


\section{REFERENCE}

Afrianti, R. 2011. Hubungan Mutu Pelayanan Keperawatan dengan Kepuasan Pasien Pengguna Jamkesmas di Ruang Rawat Inap Bangsal Bedah RSUP Dr. M. Djamil Padang Tahun 2011. Padang: Program Studi Ilmu Keperawatan STIKES Alifah Padang.

Agnes Alfani, R.P 2014. Kepuasan Pasien Di Tempat Pendaftaran Pasien Rawat Jalan Berdasarkan Jenis Pasien Di Rumah Sakit Bhayangkara Polda Daerah Istimewa Yogyakarta Tahun 2014. Tugas Akhir. Yogyakarta: DIII Rekam Medis Universitas Gadjah Mada. (Tidak Dipublikasikan)

Alimul, A.H 2013. Riset Keperawatan dan Teknik Penulisan Ilmiah. Jakarta: Salemba Medika.

Azwar, S 2014, Metode Penelitian. Yogyakarta : Pustaka Belajar

Bustami. 2011. Penjaminan Mutu Pelayanan Kesehatan dan Akseptibilitasnya. Jakarta: Erlangga

Chris Rowley dan Keith Jackson.2012. Manajemen Sumber Daya Manusia. Raja Grafindo Persada. Jakarta.

Depkes RI, 2013 Sistem Kesehatan Nasional, Jakarta : Depkes RI

Desser, Gary. 2009. Manajemen SDM Buku 1. Jakarta : Indeks.

Desser, Gary. 2009. Manajemen SDM Buku 2. Jakarta : Indeks.

Gurusinaga, Rahmad. 2015, Hubungan Perilaku Caring Perawat dan Kepuasan Pasien Rawat Inap RS Adam Malik Medan tahun 2015. Tesis: Universitas Sumatera Utara.

Hermanto. 2010. Pengaruh Persepsi Mutu Pelayanan Kebidanan Terhadap Kepuasan Pasien Rawat Inap Kebidanan Di RSUD Dr.H. Soemarno Sosroatmodjo Bulungan Kalimantan Timur. (tesis). Semarang: Universitas Diponegoro.

Jayati, Nani Dwi, 2014, Tingkat Kepuasan Keluarga Pasien Terhadap Pelayanan Pendaftaran Pasien Rawat Inap Rumah Sakit Umum Daerah Kota Yogyakarta :Tesis. Yogyakarta :Program Studi Ilmu Kesehatan Masyarakat Universitas Gadjah Mada

Mantra, Ida Bagoes, 2012, Demografi Umum, Yogyakarta: Pustaka Pelajar

Masruroh. 2015. Manajemen Sumber Daya Manusia Dalam Pelayanan Kesehatan. Jakarta.

Notoatmodjo, Soekidjo. 2010. Metodologi Penelitian Kesehatan. Jakarta: PT. Rineka Cipta.

Nursalam. 2013. Metodologi Penelitian Ilmu Keperawatan Pendekatan Praktis. Edisi 3. Jakarta: Salemba Medika

Rahmulyono, A. 2013. Analisis Pengaruh Kualitas Pelayanan Terhadap Kepuasana Pasien

Puskesmas Depok I Sleman Yogyakarta. Available from : 2008052501581504311196.pdf

Rashid Al-Abri \& Amina Al-Balushi. 2014. Patients Satisfaction Survey As A Tool Toward Quality Improvement. Journal Nurse Care Quality, Vol: 16, No: 4.

Sari, Putrianti. 2012. Tingkat Kepuasan Pasien Terhadap Penampilan Perawat Pada Saat Berkomunikasi Interpersonal Dengan Pasien di Ruang Rawat Inap Bedah RSUD Gunung Jati Cirebon. Jurnal Unpad ; Vol: 1, No: 1. 
Soekidjo, Notoatmodjo. 2009. Pengebangan Sumber Daya Manusia. Jakarta : Rineka Cipta.

Syarifudin. 2009. Mutu Pelayanan Kesehatan. Jakarta: EGC

Sugiyono. 2011. Statistik Untuk Penelitian. Jakarta : Rineka Cipta.

2013. Metode Penelitian: Pendekatan Kuantitatif, Kualitatif dan $R$ \& $D$. Bandung: Alfabeta.

Wilde Larsson. 2010. Pengukuran Tingkat Kepuasan Pelanggan. Jakarta: Salemba

Zulkarnain, Elfian , 2014 , Analisis tingkat kepuasan pasien terhadap interaksi pasien dan perawat dalam memberikan pelayanan berdasarkan karakteristik pasien. Tesis. Yogyakarta : Program Studi Ilmu Kesehatan Masyarakat Universitas Gadjah Mada 